\title{
DAMPAK PROGRAM BANTUAN TUNAI (CASH TRANSFER) TERHADAP KESEJAHTERAAN SUBJEKTIF DI INDONESIA
}

\author{
Ali Akbar Khomaini \\ Direktorat Jenderal Perbendaharaan \\ Alamat Korespondensi : aliakbar830@gmail.com
}

\begin{abstract}
Cash transfer programs have become the main poverty-alleviating policy in several developing countries. This study analyzes the perceived impact of Direct Cash Assistance (BLT) as an Unconditional Cash Transfer (UCT) program in Indonesia by examining beneficiary households' subjective wellbeing. Two rounds of Indonesian Family Life Survey (IFLS) panel data from 2007 (IFLS-4) and 2015 (IFLS-5) are used, from which this study take the subjective wellbeing indicators. Three main categories of subjective wellbeing components are developed using Principle Component Analysis (PCA): family satisfaction, future perception, and children. Ordinary Least Squares (OLS) and fixed effect methods are used to determine the impact of UCT program on subjective wellbeing. The Indonesian UCT program is negatively correlated or has no impact on improving recipients' subjective wellbeing compared to that of non-recipients. Out of the three subjective wellbeing components, family satisfaction appears to have received significant and positive impact from the UCT program. UCT may also help beneficiaries maintain stable consumption level during short-term economic shocks, but future perception and children's wellbeing perception are not found to be affected.
\end{abstract}

KATA KUNCI:

Cash Transfer, Happiness, Life Satisfaction, Subjective Wellbeing, UCT.

\begin{abstract}
ABSTRAK
Program bantuan tunai telah menjadi kebijakan pengentasan kemiskinan utama di beberapa negara berkembang. Penelitian ini menganalisis dampak yang dirasakan dari Bantuan Langsung Tunai (BLT) sebagai Unconditional Cash Transfer (UCT) atau program transfer tunai tanpa syarat di Indonesia dengan melakukan pengujian terhadap persepsi kesejahteraan secara subjektif rumah tangga penerima bantuan. Dua putaran data panel dari Indonesian Family Life Survey (IFLS) di tahun 2007 (IFLS-4) dan tahun 2015 (IFLS-5) digunakan dalam penelitian ini, dimana indikator kesejahteraan subjektif. Tiga kategori utama komponen kesejahteraan subjektif dikembangkan dengan menggunakan Principle Component Analysis (PCA) yaitu kepuasan keluarga, persepsi masa depan, dan persepsi terhadap anak-anak. Metode Ordinary Least Squares (OLS) dan Fixed Effectdigunakan untuk menentukan dampak program UCT terhadap kesejahteraan subjektif. Secara umum program UCT di Indonesia berkorelasi negatif atau tidak berdampak pada peningkatan kesejahteraan subjektif penerima dibandingkan dengan non-penerima bantuan. Kepuasan keluarga terlihat menerima dampak yang signifikan dan positif dari program UCT diantara tiga komponen kesejahteraan subjektif. UCT juga dapat membantu penerima manfaat mempertahankan tingkat konsumsi yang stabil selama guncangan ekonomi jangka pendek, tetapi tidak berpengaruh terhadap persepsi masa depan dan persepsi terhadap kesejahteraan anak-anak.
\end{abstract}

\section{KLASIFIKASI JEL:}

I38

\section{CARA MENGUTIP:}

Khomaini, A.A. (2020). Dampak program bantuan tunai (cash transfer) terhadap kesejahteraan subjektif di Indonesia. Indonesian Treasury Review: Jurnal Perbendaharaan, Keuangan Negara dan Kebijakan Publik, 5(1), 1-16. 


\section{PENDAHULUAN}

\subsection{Latar Belakang}

Program perlindungan sosial telah terbukti meningkatkan kesejahteraan material yang bertujuan untuk melindungi masyarakat dari berbagai resiko melalui bantuan tunai atau asuransi sosial. Bagi negara berkembang, program bantuan tunai telah menjadi kunci kebijakan sosial dan pengurangan kemiskinan oleh pemerintah. Sekitar 130 negara berkembang telah menjalankan minimal satu program bantuan tunai yang tidak memerlukan tindak lanjut tertentu untuk mendapatkannya, atau juga dikenal sebagai bantuan tunai tanpa syarat (Unconditional Cash Transfer/UCT), dengan pertumbuhan program yang sangat tinggi terjadi di Afrika. Program tersebut mencakup bantuan yang menargetkan kemiskinan dan pensiun sosial hari tua. Selain itu, setidaknya satu program bantuan tunai bersyarat (Conditional Cash Transfer/CCT) ditemukan di 63 negara berkembang mengalami peningkatan secara signifikan jika dibandingkan dengan tahun 1997 (dua negara) dan tahun 2008 (27 negara) (Honorati dkk., 2015). Perluasan program bantuan tunai ini diikuti dengan meningkatnya jumlah evaluasi program yang menghasilkan serangkaian bukti tentang dampak berbagai program bantuan tunai pada level individu dan rumah tangga.

Program bantuan tunai secara umum dapat diklasifikasikan menjadi dua jenis yaitu program bantuan tunai bersyarat (Conditional Cash Transfer, CCT) dan tidak bersyarat (Unconditional Cash Transfer, UCT). Sebagai kebijakan strategis, program CCT telah berhasil mengurangi kemiskinan di berbagai negara berkembang melalui program kesejahteraan yang mengharuskan penerima memenuhi persyaratan tertentu untuk menerima bantuan tunai. Berbagai kegiatan di bidang kesehatan, nutrisi, dan pendidikan menjadi tuntutan yang harus dilakukan untuk menerima CCT secara berkelanjutan. Sementara itu, program-program UCT memberikan bantuan tunai kepada individu dan rumah tangga tanpa menentukan bagaimana mereka harus menghabiskan bantuan tersebut atau mempersyaratkan tugas-tugas yang harus dilakukan untuk mendapatkan kembali bantuan. UCT yang didanai oleh pemerintah dan organisasi non-pemerintah (LSM) telah banyak membantu rumah tangga miskin dan rentan di beberapa negara berkembang (Junior dkk., 2016).

Beberapa penelitian yang dilakukan untuk menentukan dampak program bantuan tunai, baik bersyarat atau tanpa syarat, telah menunjukkan hasil positif melalui pendekatan objektif dan menggunakan indikator sosial, seperti pendidikan, kesehatan, konsumsi rumah tangga, kemiskinan, dan ketidaksetaraan sebagai proksi (Saavedra,
2016; Attah, dkk., 2016). Menurut Martínez, D.M. \& Maia, A.G. (2018), pendekatan objektif berguna untuk menentukan berbagai aspek kondisi kehidupan seseorang, sedangkan indikator subjektif digunakan untuk mengukur persepsi seseorang tentang kondisi kehidupannya. Indikator kesejahteraan subjektif memberikan informasi yang sangat berguna ketika merencanakan, mengembangkan, dan mengevaluasi kebijakan publik terkait pengentasan kemiskinan dan ketidaksetaraan. Namun, penelitian tentang dampak program bantuan tunai terhadap kesejahteraan subjektif sejauh ini masih langka.

UCT telah terbukti memiliki dampak positif pada sejumlah variabel objektif seperti pengeluaran rumah tangga, kesehatan, pertumbuhan, dan gizi anak, perkawinan remaja, dan angka kehamilan, serta pencapaian pendidikan (Junior dkk., 2016). Namun demikian, dengan pengukuran program bantuan yang terkonsentrasi pada hasil material, belum diketahui secara pasti apakah UCT juga meningkatkan kesejahteraan immaterial penerima. Pada saat yang sama, pendapatan seseorang dan ukuran moneter lain yang digunakan oleh para ekonom tidak dapat sepenuhnya memperhitungkan aspek fundamental kehidupan manusia seperti kepuasan hidup yang dapat digunakan untuk mengukur peningkatan kualitas kehidupan.

Hal Ini sejalan dengan pandangan Stiglitz, Sen, dan Fitoussi dalam Saavedra (2016) yang menyatakan bahwa dihadapkan pada keterbatasan paradigma dominan dan tren yang sudah ada untuk pendekatan yang lebih berpusat pada manusia. Para peneliti, pembuat kebijakan, dan pemerintah semakin mengakui bahwa pembangunan dan kemajuan sosial tidak dapat dipersempit menjadi ukuran kinerja ekonomi dan indikator terkait semata, tetapi pengalaman masyarakat dan penilaian subjektif tentang apa yang penting dalam kehidupan mereka juga perlu dipertimbangkan.

Saat ini telah muncul kesadaran diantara para peneliti tentang pentingnya pengukuran kualitas hidup sebagai pengalaman aktual melalui persepsi individu dan rumah tangga, seperti kesejahteraan subjektif (Saavedra, 2016). Tujuan dari pengukuran ini adalah untuk mendapatkan gambaran lebih jelas tentang dampak program pada kesejahteraan. Studi terbaru semakin fokus pada dampak program UCT terhadap pengalaman subjektif.

Samuel, F. \& Stavropoulou, M (2016) dengan menggunakan bukti empiris kuantitatif menemukan bahwa program bantuan tunai di seluruh Timur Tengah dan Sub-Sahara Afrika telah menunjukkan efek psikososial yang positif. Selain itu, Attah dkk., (2016) menemukan bahwa 
peningkatan kesejahteraan psikososial memiliki dampak positif yang meluas pada pengambilan keputusan di antara bidang kehidupan lainnya.

Akan tetapi, bukti empiris tentang korelasi antara bantuan tunai dan kesejahteraan subjektif tidak konklusif dan terbatas. Rojas (2008) dalam penelitiannya menemukan disonansi antara kesejahteraan subjektif dan objektif di mana peningkatan pendapatan rumah tangga dalam program Mexico's Opportunitiesbelum mengarah pada rasa kesejahteraan subjektif yang lebih tinggi

Indonesia memperkenalkan sejumlah program bantuan tunai dalam dekade terakhir. Setelah krisis ekonomi di Asia Timur, pemerintah Indonesia telah menerapkan program bantuan sosial darurat untuk rakyat miskin, selanjutnya disederhanakan menjadi program jaring pengaman sosial pada tahun 1999. Selain itu, program UCT (Bantuan Langsung Tunai/BLT) dan program CCT (Program Keluarga Harapan/PKH) diperkenalkan masing-masing pada tahun 2005 dan 2007. Pemerintah telah merencanakan untuk mengintegrasikan program bantuan tunai ke dalam sistem perlindungan sosial nasional.

Pemerintah Indonesia segera bereaksi dengan memperkenalkan UCT (BLT) sebagai alat kebijakan alternatif untuk mengimbangi kenaikan harga bahan bakar ketika harga minyak dunia naik pada tahun 2005. Jumlah uang tunai yang diterima per bulan oleh setiap rumah tangga target adalah IDR100.000 (sekitar USD 10) dan program ini mencakup 15,5 juta rumah tangga. Selanjutnya Skema Bantuan Tunai Tanpa Syarat ini dihentikan setelah hampir setahun berjalan. Akan tetapi, harga beras domestik naik pada Januari 2008. Pemerintah Indonesia kemudian tidak memiliki pilihan lain selain memperkenalkan kembali UCT, dan diimplementasikan kembali antara Bulan Juni dan Bulan Desember 2008 yang menyerap biaya lebih dari Rp13 triliun dan mencakup 19 juta rumah tangga. Meskipun UCT telah digunakan sebagai alat kebijakan untuk merespon keadaan darurat sosial dengan cepat,hal ini tidak dapat bertahan lama karena terkait beban keuangan pemerintah yang cukup berat.

Akibatnya, pemerintah mulai mengganti UCT dengan CCT pada tahun 2006 melalui proyek yang dikenal sebagai Program Keluarga Harapan (PKH). Indonesia mengandalkan dukungan teknis dari organisasi internasional selama fase persiapan program, seperti USD2,6 juta yang diterima sebagai bantuan teknis dari Asian Development Bank (ADB) selama 18 bulan dan dana ini digunakan untuk program percontohan. Selain itu, Bank Dunia memberikan dukungan teknis yang diperlukan untuk menerapkan CCT dan membantu membangun sistem penargetan.
Studi tentang dampak program bantuan tunai (bersyarat dan tanpa syarat) di Indonesia sebagian besar menggunakan indikator objektif seperti pengeluaran, pasokan tenaga kerja, pendidikan, kesehatan, dan gizi. Berdasarkan alasan yang dikemukakan di atas, penelitian ini mencoba mengevaluasi dampak program bantuan tunai di Indonesia dalam perspektif kesejahteraan subjektif. Penelitian ini memilih fokus pada program Bantuan Tunai Tanpa Syarat (UCT) dikarenakan adanya keterbatasan data untuk Program Bantuan Tunai Bersyarat (CCT) dalam dataset yang ada.

\subsection{Pertanyaan Penelitian}

Penelitian ini akan mengevaluasi dampak program Bantuan Tunai Tanpa Syarat (Unconditional Cash Transfer, UCT) di Indonesia terhadap kesejahteraan subjektif rumah tangga. Studi ini membahas pertanyaan-pertanyaan berikut untuk mencapai tujuan utama:

1. Apa dampak program UCT (BLT) terhadap kesejahteraan subjektif dari penerima dibandingkan dengan non-penerima bantuan?

2. Komponen kesejahteraan subjektif manakah yang menerima dampak paling besar dari program UCT (BLT)?

Penelitian ini bertujuan untuk melengkapi literatur tentang dampak UCT dengan memasukkan aspek lain dari kondisi kehidupan, serta untuk memahami secara komprehensif berbagai bentuk masalah sosial. Secara teoritis, intervensi dalam perlindungan sosial seperti bantuan tunai akan mengurangi berbagai risiko dan secara bersamaan meningkatkan kesejahteraan secara psikologis. Tetapi studi yang melibatkan aspek non-material yang didasarkan pada persepsi penerima bantuan UCT masih jarang. Pembuat kebijakan dapat menggunakan hasil penelitian ini untuk mengevaluasi efektivitas program UCT dalam meningkatkan kualitas hidup pada rumah tangga penerima.

\section{LANDASAN TEORI}

\subsection{Kesejahteraan Subjektif}

Kesejahteraan subjektif merupakan gagasan yang luas dan terdiri dari banyak dimensi. Diener dkk, (2009) menjelaskan, kesejahteraan subjektif dihasilkan melalui evaluasi emosional atau kognitif seseorang terhadap kehidupan mereka. Kesejahteraan subjektif yang tinggi mengindikasikan pemikiran berulang tentang pengalaman positif dan kepuasan hidup yang tinggi.

Persepsi kesejahteraan personal secara psikologis sangat terkait dengan perilaku ekonomi dan sosial. Pengambil keputusan dengan 
pandangan hidup yang positif diharapkan dapat menentukan pilihan terbaik terkait masalah individu dan rumah tangga, seperti perawatan kesehatan dan pengembangan diri yang lebih baik. Kebahagiaan yang dicapai dari pandangan positif dapat meningkatkan fleksibilitas kognitif dan mendorong evaluasi yang cermat terhadap masa depan. Untuk keluarga miskin, pandangan positif tentang kehidupan menjadi faktor penentu terkait keputusan antara melepaskan diri atau bertahan dalam kemiskinan (Kilburn dkk, 2016).

Diener dkk, (1995) berpendapat bahwa kondisi kesejahteraan subjektif dipengaruhi oleh beberapa faktor, termasuk karakter pribadi dan kondisi lingkungan. Sementara itu, para peneliti juga menekankan pengaruh kondisi materi, yaitu bahwa semakin banyak sumber daya keuangan membuka lebih banyak kemungkinan konsumsi yang pada gilirannya membuat individu lebih bahagia dan kualitas hidup lebih baik. Akan tetapi, tidak ada kesepakatan bersama tentang validitas aturan ini di negara-negara maju, Handadkk(2014) berpendapat bahwa korelasi positif antara kondisi ekonomi dan kualitas hidup lebih kuat di negaranegara berkembang.

Konsep kesejahteraan subjektif menurut Maslow dalam Handa dkk(2014) terkait dengan hierarki kebutuhan, di mana kualitas hidup orang miskin terkait erat dengan pemenuhan kebutuhan dasar. Oleh karena itu, jika elemen manusia secara alami terkait dengan pemenuhan diri, kebijakan publik dapat mempengaruhi kesejahteraan subjektif dengan mengubah lingkungan eksternal.

Kuznets (dalam Wills,2009) berpendapat bahwa pengukuran kepuasan hidup secara subjektif yang menilai kesejahteraan seseorang adalah indikator paling signifikan untuk mengetahui kualitas hidup masyarakat dalam skala nasional, lokal, atau perkotaan, dimana didalamnya tidak hanya ukuran kinerja variabel kontekstual yang seharusnya dimasukkan, tetapi juga persepsi terhadap kesejahteraan masyarakat. Indikator kesejahteraan objektif seperti pendapatan seseorang atau output moneter lainnya telah gagal mengukur bagaimana orang memandang kualitas hidup mereka.

Studi empiris menunjukkan bahwa di negaranegara industri, kesejahteraan meningkat dengan meningkatnya pendapatan nasional, tetapi hanya pada tingkat tertentu. Di tingkat selanjutnya, peningkatan kesejahteraan tersebut begitu kecil sehingga menjadi hampir tidak terdeteksi (Eckersley, R, 2000). Setelah level tertentu dipenuhi, kenaikan pendapatan tidak lagi diimbangi dengan peningkatan kepuasan hidup, terutama di negara-negara maju (Helliwell 2005).

\subsection{Bantuan Tunai dan Kesejahteraan Subjektif}

Pentingnya kesejahteraan subjektif dalam menentukan persepsi kualitas hidup seseorang menjadikan hal ini sebagai instrumen yang kuat dalam menilai dampak kebijakan sosial terhadap kemiskinan dan kesejahteraan. Rawlings, L. B. \& Rubio, G. (2003) menekankan pentingnya program bantuan tunai di antara kebijakan sosial lain, dikarenakan bantuan tunai bertujuan meningkatkan kapasitas sumber daya manusia melalui penyediaan uang tunai untuk keluarga miskin. Selain itu, ketika individu atau rumah tangga menerima pembayaran tunai langsung sesuai kebutuhan, bagaimana mereka memanfaatkan uang menentukan pengeluaran dan tabungan rumah tangga (Bastagli dkk, 2016). Oleh karena itu, bantuan ini dapat memiliki efek jangka panjang pada kualitas hidup rumah tangga dan akumulasi aset jika digunakan secara tepat, sehingga mengurangi kemiskinan dan meningkatkan kesejahteraan.

Membahas dampak bantuan tunai pada kesejahteraan psikologis, Samuel, F. \& Stavropoulou, M. (2016) menemukan bahwa bantuan tunai dapat meningkatkan keamanan finansial, sehingga menurunkan stres dan kecemasan. Bahkan ketika bantuan tunai tidak cukup untuk memenuhi semua kebutuhan, adanya bantuan dapat membantu penerima menghadapi kesulitan sehari-hari dan menutupi biaya makanan, pendidikan, dan medis. Keteraturan dan prediktabilitas yang terkait dengan bantuan tunai juga memberikan perasaan aman secara ekonomi dan mengurangi stres dan kecemasan. Pada saat yang sama, ketergantungan hidup terhadap orang lain menurun mengarah pada peningkatan kontrol kehidupan (kepercayaan finansial). Bantuan tunai dianggap lebih baik dalam mengurangi ketergantungan pada orang lain dibandingkan dengan jenis bantuan lainnya dan memungkinkan penerima manfaat mempertahankan kendali atas kehidupan mereka. Beberapa penerima manfaat bahkan merasa lebih meningkatkan pemberdayaan diri.

Selain itu, Pega dkk(2017) menemukan bagaimana bantuan tunai terkait dengan pengentasan kemiskinan berdampak luas ke aspek kesehatan. Jalur sebab akibat utama dampak bantuan tunai adalah melalui pendapatan. Hal ini dapat mengurangi risiko kemiskinan dan dengan sendirinya berpotensi meningkatkan aspek kesehatan di rumah tangga penerima. Pendapatan dari bantuan tunai yang dibiayai oleh dana publik dapat memengaruhi kesehatan individu. Selanjutnya, Kahneman, D. \&Deaton, A. (2010) menemukan bahwa kepuasan hidup dan kesejahteraan emosional meningkat dengan meningkatnya pendapatan. 
Disisi lain, Rojas (2009) berpendapat bahwa kesejahteraan subjektif mencakup banyak dimensi dalam ranah kehidupan kita, di mana pendapatan hanyalah salah satu penentu kesejahteraan. Gagasan tentang domain kehidupan terkait dengan pandangan bahwa kesejahteraan seseorang bergantung pada kepuasan pada banyak bidang kehidupan, sehingga pada gilirannya bergantung pada banyak faktor selain pendapatan, seperti usia, tingkat pendidikan, kesehatan, jenis hobi dan hiburan, jenis pekerjaan, tempat tinggal, sifat dan kekuatan hubungan interpersonal, dan sebagainya. Dalam pandangan ini, pendapatan dan kesejahteraan subjektif tidak menunjukkan hubungan korelasi yang kuat.

\subsection{Penelitian Terdahulu}

Menggabungkan desain kluster longitudinal, randomized, dan panel data dari 3365 rumah tangga miskin, Kilburn dkk, (2016) beralih ke Malawi untuk melihat dampak program Bantuan Tunai Tanpa Syarat (unconditional cash transfer, UCT) pada kesejahteraan subjektif. Penelitian menunjukkan bahwa peningkatan pendapatan rumah tangga dari bantuan tunai dapat memiliki efek besar pada kesejahteraan subjektif penerima. Rumah tangga menggunakan uang tunai untuk meningkatkan mata pencaharian keluarga mereka dan memastikan pemenuhan kebutuhan dasar, termasuk makanan, pakaian, dan tempat tinggal. Bantuan tunai membuat penerima manfaat lebih bahagia dalam jangka pendek dan memberi mereka harapan untuk masa depan yang lebih baik dengan mengurangi tekanan kebutuhan harian.

Selain itu, Haushofer, J. \& Shapiro, J. (2016) menyelidiki respon rumah tangga miskin di pedesaan Kenya terhadap perubahan signifikan sementara dalam pendapatan mereka.LSM GiveDirectly menggunakan randomized control trial untuk secara acak mengalokasikan setidaknya USD 404 UCT untuk rumah tangga. Haushofer, J. \& Shapiro, J. (2016) menemukan bahwa penerima manfaat mengalami peningkatan substansial dalam kesejahteraan psikologis dan penurunan tingkat stres. Temuan ini menunjukkan bahwa UCT memiliki efek signifikan pada konsumsi dan kesejahteraan psikologis.

Natali, dkk (2018) baru saja melakukan penelitian dampak bantuan uang tunai tanpa syarat (UCT) terhadap kebahagiaan perempuan miskin. Natali, dkk. (2018) menggunakan randomized controlled trial pada 90 komunitas di daerah pedesaan Zambia. Hasil penelitianmenemukan dampak sebesar 7,5-10 poin persentase peningkatan pada kebahagiaan wanita setelah 36 dan 48 bulan program berjalan. Selain itu, penerima manfaat melaporkan kepuasan secara keseluruhan yang meningkat terhadap kesejahteraan anak-anak mereka, termasuk kepuasan tentang kesehatan anak dan perspektif positif tentang masa depan anak.

\section{METODOLOGI PENELITIAN}

\subsection{Data}

Penelitian ini menggunakan data dari Survei Kehidupan Keluarga Indonesia (Indonesia Family Life Surveying/IFLS), survei yang dilakukan oleh RAND Corporation bekerja sama dengan pusat penelitian beberapa universitas di Indonesia. Sampel awal IFLS mewakili 83 persen populasi Indonesia yang tinggal di 13 provinsi. IFLS adalah survei longitudinal rumah tangga Indonesia dan survei paling komprehensif yang pernah dilakukan di Indonesia yang mencakup berbagai aspek kehidupan rumah tangga dan individu. Penelitian ini adalah studi panel rumah tangga, individu, dan fasilitas publik yang telah dilakukan sebanyak lima gelombang survei terintegrasi sejak tahun 1993. Data dari gelombang survei keempat (IFLS-4) dan kelima (IFLS-5) digunakan untuk penelitian ini. Survei dilakukan pada tahun 2007, IFLS-4 mencakup wawancara dengan 13.500 rumah tangga dan 43.000 individu. IFLS-5 dilakukan pada akhir 2014 dan terjadi peningkatan jumlah responden yang diwawancarai yaitu sebanyak 15.900 rumah tangga dan 50.000 individu.

Data penerima manfaat program UCT (BLT) dan kesejahteraan subjektif diambil dari Buku 1 dan 3A IFLS di mana informasi tentang apakah kepala rumah tangga menerima BLT serta komponen kesejahteraan subjektif dapat ditemukan. Variabel independen utama adalah partisipasi responden dalam program BLT yang merupakan variabel dummy dengan nilai 1 untuk penerima (treatment) atau 0 untuk non-penerima (control). Responden sampel untuk kelompok treatment dan control merupakan termasuk kategori miskin dengan total panel rumah tangga sebanyak 11.340 responden yang terdiri dari 3.101 penerima UCT dan 8.239 bukan penerima.

\subsection{Principal Component Analysis(PCA)}

Variabel dependen dalam penelitian ini terdiri dari semua indikator kesejahteraan subjektif yang diambil dari beberapa pertanyaan dengan skala pilihan ganda sebagai jawaban dari survei kesejahteraan subjektif dalam Buku 3A IFLS. Berdasarkan pertanyaan kesejahteraan subjektif tersebut, dibuat tiga kategori utama komponen kesejahteraan subjektif yaitu: kepuasan keluarga, persepsi masa depan, dan persepsi terhadap anakanak. Tabel 1 merinci setiap komponen kesejahteraan subjektif: 
6

Tabel 1. Komponen Kesejahteraan Subjektif

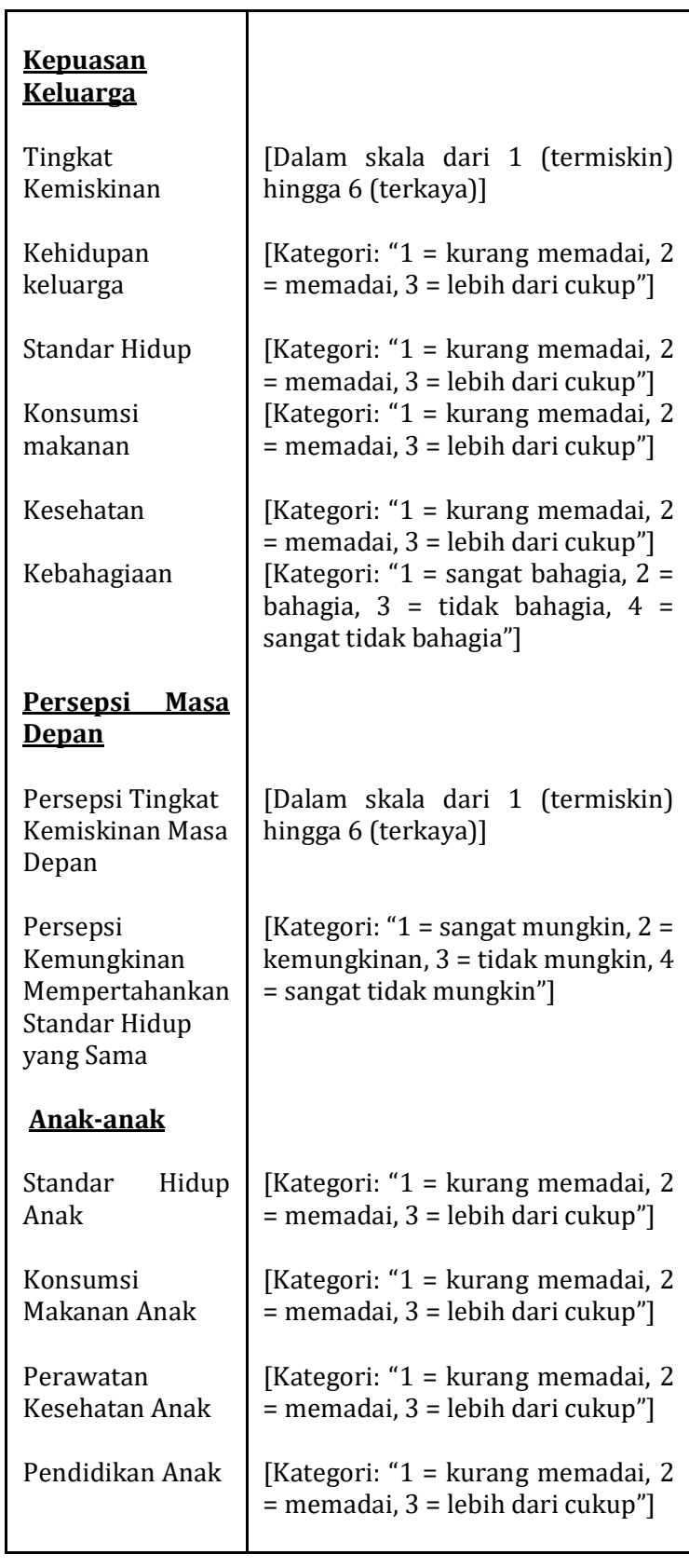

Sumber: IFLS, diolah

Tiga indeks digunakan untuk variabel dependen, yaitu kepuasan keluarga, persepsi masa depan, dan anak-anak. Kepuasan keluarga dibangun pada beberapa pertanyaan dengan skala multi-point untuk menjawab setiap pertanyaan. Pertanyaan pertama tentang tingkat kemiskinan datang dengan enam kemungkinan tanggapan mulai dari yang termiskin (1) hingga yang terkaya (6). Pertanyaan tentang kehidupan keluarga rumah tangga, standar hidup, konsumsi makanan, dan perawatan kesehatan datang dengan tiga poin tanggapan dari "kurang memadai" sampai "lebih dari cukup." Pertanyaan terakhir tentang tingkat kebahagiaan diukur pada skala dari 1 (sangat bahagia) ke 4 (sangat tidak bahagia).

Persepsi masa depan dibangun atas dua pertanyaan tentang apa yang dirasakan kepala rumah tangga, pertama, tingkat kemiskinan dalam lima tahun kedepan dengan pilihan jawaban mulai dari 1 (termiskin) hingga 6 (terkaya), dan kedua, apakah standar kehidupan tetap sama setelah lima tahun kedepan dengan mempertimbangkan perubahan harga saat ini dengan kisaran jawaban dari 1 (sangat mungkin) hingga 4 (sangat tidak mungkin).

Komponen ketiga, persepsi tentang anakanak, dibangun berdasarkan pertanyaan tentang standar hidup anak-anak, konsumsi makanan, perawatan kesehatan, dan pendidikan anak-anak dengan jawaban berkisar dari 1 (kurang dari cukup) hingga 3 (lebih dari cukup).

Principal Component Analysis (PCA) adalah sebuah teknik untuk membangun variabel baru yang merupakan kombinasi linear dari variabel asli dan digunakan untuk membuat indeks untuk ketiga variabel dependen. Jumlah maksimum variabel baru akan sama dengan jumlah variabel lama, dan variabel-variabel baru ini tidak saling berkorelasi. Jamal, H. (2018) menyatakan bahwa Teknik PCA terutama digunakan untuk menyelesaikan masalah substitusi antara komponen dan pemberian bobot pada konstituen indeks komposit. Dengan demikian, penerapan bobot statistik untuk membangun indeks komposit adalah pilihan lebih baik karena ini menghilangkan subjektivitas dan bias pribadi. Tiga indeks komponen dan indikator untuk variabel dependen adalah sebagai berikut:

Table 2. Variabel KesejahteraanSubjektif

\begin{tabular}{lll}
\hline $\begin{array}{l}\text { Komponen } \\
\text { Kesejahteraan } \\
\text { Subjektif }\end{array}$ & Indikator & $\begin{array}{l}\text { Kode } \\
\text { IFLS }\end{array}$ \\
\hline & Tingkat Kemiskinan & sw01 \\
\cline { 2 - 3 } $\begin{array}{l}\text { Kepuasan } \\
\text { Keluarga } \\
\text { (fam_sat) }\end{array}$ & Kehidupan keluarga & sw03b \\
\cline { 2 - 3 } & Standar Hidup & sw04 \\
\cline { 2 - 3 } & Konsumsi makanan & sw05 \\
\cline { 2 - 3 } & Kesehatan & sw06 \\
\cline { 2 - 3 } $\begin{array}{l}\text { Persepsi Masa } \\
\text { Depan } \\
\text { (fut_pers) }\end{array}$ & $\begin{array}{l}\text { Kebahagiaan } \\
\text { masa depan }\end{array}$ & $\begin{array}{l}\text { Persepsi kemungkinan } \\
\text { mempertahankan standar }\end{array}$ \\
\hline \multirow{2}{*}{$\begin{array}{l}\text { Anak-anak } \\
\text { (child) }\end{array}$} & sw3ai & \\
\cline { 2 - 3 } & Konsumsing sama & sw08 \\
\cline { 2 - 3 } & Kesehatan & sw09 \\
\cline { 2 - 3 } & Pendidikan & sw11 \\
\hline
\end{tabular}

Sumber : IFLS, diolah 
PCA diterapkan pada masing-masing komponen kesejahteraan subjektif yaitu kepuasan keluarga, persepsi masa depan, dan anak-anak. Hasilnya disajikan di bawah ini:

\subsubsection{PCA kesejahteraan subjektif-kepuasan keluarga}

Beberapa faktor yang relevan terbentuk ketika menerapkan metode PCA, yang diwakili oleh Comp1 ke Comp6. Nilai eigen, variabilitas, dan variabilitas kumulatif ditampilkan pada tabel berikut:

Table 3.Nilai Eigen, Variabilitas, dan Variabilitas Kumulatif Indikator Kepuasan Keluarga

\begin{tabular}{|c|c|c|c|}
\hline Komponen & Nilai eigen & $\begin{array}{c}\text { Variabilitas } \\
\text { (\%) }\end{array}$ & $\begin{array}{c}\text { Kumulatif } \\
\text { (\%) }\end{array}$ \\
\hline Comp1 & 2.96811 & 49.47 & 49.47 \\
Comp2 & 0.906498 & 15.11 & 64.58 \\
Comp3 & 0.821079 & 13.68 & 78.26 \\
Comp4 & 0.598868 & 9.98 & 88.24 \\
Comp5 & 0.430385 & 7.17 & 95.42 \\
Comp6 & 0.275064 & 4.58 & 100 \\
\hline
\end{tabular}

Sumber: hasil STATA dan perhitungan penulis

Berdasarkan output di atas, variabel yang dianalisis dapat dikelompokkan menjadi satu faktor, yaitu yang dengan nilai eigen lebih besar dari satu. Nilai eigen kurang dari satu tidak dapat digunakan dalam menghitung jumlah faktor yang terbentuk, sehingga proses factoring berhenti pada faktor pertama. Faktor 1 memiliki nilai eigen 2,96811 dan menjelaskan 49,47 persen dari total komunal.

Komponen kepuasan keluarga dari kesejahteraan subjektif diukur oleh enam indicator, yaitu tingkat kemiskinan (sw01), standar hidup (sw04), konsumsi makanan (sw05), kesehatan (sw06), kebahagiaan (sw12i), dan kehidupan keluarga (sw03b). Hasil PCA untuk variabel-variabel ini adalah sebagai berikut:

Table 4. Indikator Kepuasan Keluarga terhadap Komponen Utama oleh PCA

\begin{tabular}{|c|c|}
\hline Variable & Component 1 \\
\hline sw01 & 0.2635 \\
sw04 & 0.4963 \\
sw05 & 0.4649 \\
sw06 & 0.4105 \\
sw12i & 0.2548 \\
sw03b & 0.4844 \\
\hline
\end{tabular}

Sumber: hasil STATA

Berdasarkan hasil di atas, persamaan untuk indeks kepuasan keluarga ditetapkan sebagai berikut: fam_sat $=0.2635$ sw01 +0.4963 sw04 +0.4649

sw05 + 0.4105 sw06 +0.2548 sw12i +0.4844 sw03b

\subsubsection{PCA kesejahteraan subjektif - persepsi masa depan}

Tabel 5 di bawah ini menunjukkan nilai eigen, variabilitas, dan variabilitas kumulatif PCA untuk indeks persepsi masa depan.

Tabel 5. Nilai Eigen, Variabilitas, dan Variabilitas Kumulatif Indikator Persepsi Masa Depan

\begin{tabular}{|c|c|c|c|}
\hline Komponen & Nilai eigen & $\begin{array}{c}\text { Variabilitas } \\
\text { (\%) }\end{array}$ & $\begin{array}{c}\text { Kumulatif } \\
\text { (\%) }\end{array}$ \\
\hline Comp1 & 1.08705 & 54.35 & 54.35 \\
Comp2 & 0.912953 & 45.65 & 100 \\
\hline
\end{tabular}

Sumber: hasil STATA dan perhitungan penulis

Sekali lagi, hanya satu faktor yang terbentuk di sini. Faktor 1 memiliki nilai eigen 1,08705 dan menjelaskan 54,35 persen dari total komunal.

Komponen persepsi masa depan tentang kesejahteraan subjektif diukur dengan persepsi tingkat kemiskinan masa depan (sw02) dan persepsi kemungkinan mempertahankan standar hidup yang sama (sw3ai). Hasil PCA dari variabelvariabel ini adalah sebagai berikut.

Table 6. Indikator Persepsi Masa Depan untuk Komponen Utama oleh PCA

\begin{tabular}{|c|c|}
\hline Variable & Component 1 \\
\hline sw02 & 0.7071 \\
sw03ai & 0.7071 \\
\hline
\end{tabular}

Sumber: hasil STATA dan perhitungan penulis

Berdasarkan hasil di atas, persamaan untuk indeks persepsi masa depan ditetapkan sebagai berikut:

fut_pers $=0.7071 \mathrm{sw} 02+0.7071 \mathrm{sw} 03 \mathrm{ai}$

\subsubsection{PCA kesejahteraan subjektif - anak-anak}

Nilai eigen, variabilitas, dan variabilitas kumulatif PCA pada persepsi tentang anak-anak disediakan di bawah ini.

Table 7. Nilai Eigen, Variabilitas, dan Variabilitas Kumulatif Indikator Anak

\begin{tabular}{|c|c|c|c|}
\hline Komponen & Nilai eigen & $\begin{array}{c}\text { Variabilitas } \\
(\%)\end{array}$ & $\begin{array}{c}\text { Kumulatif } \\
(\%)\end{array}$ \\
\hline Comp1 & 2.70091 & 67.52 & 67.52 \\
Comp2 & 0.66322 & 16.58 & 84.1 \\
Comp3 & 0.342795 & 8.57 & 92.67 \\
Comp4 & 0.293073 & 7.33 & 100 \\
\hline
\end{tabular}

Sumber: hasil STATA dan perhitungan penulis 
Hanya satu faktor yang terbentuk (Faktor 1) dengan nilai eigen 2.70091 yang menyumbang 67,52 persen dari total komunal.

Komponen kesejahteraan subjektif ini diukur oleh empat indikator: standar hidup anak-anak (sw08), konsumsi makanan anak-anak (sw09), kesehatan anak-anak (sw10), dan pendidikan anak-anak (sw11). Hasil PCA untuk variabelvariabel ini adalah sebagai berikut.

Table 8. Indikator Anak-Anak terhadap Komponen Utama oleh PCA

\begin{tabular}{|c|c|}
\hline Variable & Component 1 \\
\hline sw08 & 0.5220 \\
sw09 & 0.5350 \\
sw10 & 0.5251 \\
sw11 & 0.4068 \\
\hline
\end{tabular}

Sumber: hasil STATA

Berdasarkan hasil di atas, persamaan berikut ditetapkan untuk indeks anak-anak adalah:

Children $=0,5220$ sw08 $+0,5350$ sw09 + $0,5251 \mathrm{sw} 10+0,4068 \mathrm{sw} 011$

Skor faktor yang dihasilkan dapat digunakan untuk menggantikan skor dari variabel asli. Hasil PCA untuk setiap komponen kemudian diregresikan atau dianalisis pengaruhnya terhadap variabel independen menggunakan analisis regresi linier.

Beberapa variabel independen (kovariat) yang digunakan dalam studi ini didasarkan pada literatur tentang kesejahteraan subjektif. Dolan dkk, (2008), menyebutkan karakteristik pribadi dan sosial seperti jenis kelamin, pendidikan, status perkawinan, dan status kesehatan sebagai faktor yang mempengaruhi kesejahteraan subjektif. Sementara itu, Kilburn, dkk. (2016) menggunakan ukuran rumah tangga, usia, dan usia kuadrat sebagai variabel kontrol. Disisi lain, variabel kepemilikan rumah disarankan oleh Martínez, D.M. \& A.G. Maia, A.G. (2018).

\subsection{Model Empiris}

Model empiris yang digunakan untuk mengukur kesejahteraan subjektif banyak ditemukan dalam literatur. Kilburn, dkk. (2016) menyarankan bahwa pengukuran kesejahteraan subjektif (subjective wellbeing, SWB) yang dilaporkan sendiri oleh individu dimodelkan secara empiris sebagai fungsi tambahan faktor ekonomi, sosial, dan lingkungan di mana kesalahan residu (error term) akan mencakup perbedaan individu dalam pelaporan. Kilburn, dkk. (2016) menyatakan bahwa Tim Bantuan Tunai Sosial Malawi menggunakan model yang sama ketika meneliti dampak UCT di Malawi. yaitu menggunakan pendekatan kesejahteraan subjektif. Penelitian ini juga memakai model yang sama dengan model Kilburn dkk (2016).

Persamaan dasar untuk model ini adalah sebagai berikut:

$$
S W B_{i t}=\alpha+\beta_{1} U C T_{i t}+\beta_{x} \operatorname{Cov}_{i t}+\mu_{i t}
$$

dimana:

$$
\begin{array}{rrrl}
\text { SWB } & : & \text { komponen kesejahteraan subjektif } \\
\text { UCT } & : & \text { variabel dummy yang menyatakan } \\
& \text { apakah kepala rumah tangga } \\
& & \text { menerima UCT (1 atau 0) } \\
\text { Cov } & : & \text { kovariat } \\
\mu & : & \text { error term } \\
i & : & \text { rumah tangga } \\
t & : \text { tahun }
\end{array}
$$

Dua metode empiris digunakan untuk menentukan dampak program BLT pada kesejahteraan subjektif.

Pertama, model regresi linier OLS digunakan pada dua gelombang data IFLS (IFLS4-2007 dan IFLS5-2015).

(1) $S W B_{i}=\alpha+\beta_{1} U C t_{i}+\beta_{x} \operatorname{Cov}_{i}+\mu_{i}$

Kedua, model efek tetap (fixed effect) digunakan sesuai saran Kilburn, dkk. (2016) yang menyatakan bahwa model efek tetap digunakan untuk mengontrol perbedaan pelaporan individu dan karakteristik yang tidak teramati seperti kepribadian yang mungkin bias di dalam treatment effects. Hal ini muncul dalam kesalahan yang tidak teramati (unobserved error term) dan diasumsikan tetap dari waktu ke waktu. Efek tetap individual juga akan menghilangkan variabel kontrol yangstabil seperti jenis kelamin dan treatment status.

Kelemahan dari persamaan (1) di atas adalah adanya variabel waktu-invarian (time-invariant) yang tidak teramati, mempengaruhi kesejahteraan subjektif, dan implementasi bantuan tunai serta menyebabkan bias. Contohnya adalah kriteria kelayakan yang tidak acak dan dapat mempengaruhi hasil, misalnya tidak semua penerima bantuan adalah rumah tangga miskin. Selain itu, karena kepala desa mendistribusikan uang tunai langsung ke rumah tangga miskin, ada juga kemungkinan mis-alokasi karena faktor-faktor yang tidak teramati seperti kesalahan dalam pelaporan kondisi rumah tangga. Sumber bias lainnya juga termasuk karakteristik lokasi yang tidak teramati dan tidak berubah secara waktu seperti faktor geografis, perbedaan budaya di desa dan kota, dan perbedaan dalam preferensi rumah tangga yang mempengaruhi kesejahteraan subjektif. Kurangnya informasi tentang faktorfaktor ini berarti bahwa variabel-variabel ini harus dimasukkan dalam error term. 
Oleh karena itu, penelitian ini memilih menggunakan metode efek tetap (fixed effect)untuk mengontrol karakteristik yang tidak teramati dan mengatasi masalah bias. Dengan menggunakan metode efek tetap di tingkat rumah tangga dan sesuai dengan Wooldridge (2006), persamaan (1) menjadi sebagai berikut:

(2) $S W B_{i t}=\alpha+\beta_{1} U C t_{i t}+\beta_{x} \operatorname{Cov}_{i t}+a_{i}+\mu_{i t}$

Model persamaan untuk setiap komponen kesejahteraan subjektif dalam penelitian ini adalah sebagai berikut:

$$
\begin{aligned}
& \text { fam_sat }_{i t}=\alpha+ \beta_{1} U C t_{i t}+\beta_{2} \text { urban }_{i t} \\
&+\beta_{3} \text { home_ownership }_{i t} \\
&+\beta_{4} \text { educational_level }_{i t} \\
&+\beta_{5} \text { hhsize }_{i t}+\beta_{6} \text { age }_{i t} \\
&+\beta_{7} \text { age }_{i t}^{2}+\beta_{8} \text { marital_status }_{i t} \\
&+\beta_{9} \text { gender }_{i t} \\
&+\beta_{10} \text { health_status }_{i t}+a_{i}+\mu_{i t} \\
& \text { fut_pers }_{i t}=\alpha+ \beta_{1} \text { UCt } t_{i t}+\beta_{2} \text { urban }_{i t} \\
&+\beta_{3} \text { home_ownership } \\
&+\beta_{4} \text { educational_level } \\
&+\beta_{5} \text { hhsize }_{i t}+\beta_{6} \text { age }_{i t} \\
&+\beta_{7} \text { age }_{i t}^{2}+\beta_{8} \text { marital_status }_{i t} \\
&+\beta_{9} \text { gender }_{i t} \\
&+\beta_{10} \text { health_status }_{i t}+a_{i}+\mu_{i t} \\
& \\
& \text { child }_{i t}=\alpha+t_{i t}+\beta_{2} \text { urban }_{i t} \\
&+\beta_{3} \text { home_ownership }_{i t} \\
&+\beta_{4} \text { educational_level }_{i t} \\
&+\beta_{5} \text { hhsize }_{i t}+\beta_{6} \text { age }_{i t} \\
&+\beta_{7} \text { age }_{i t}^{2}+\beta_{8} \text { marital_status }_{i t} \\
&+\beta_{9} \text { gender }_{i t} \\
&+\beta_{10} \text { health_status }_{i t}+a_{i}+\mu_{i t}
\end{aligned}
$$

\begin{tabular}{|c|c|}
\hline age & : usia responden \\
\hline$a g e^{2}$ & : usia responden kuadrat \\
\hline marital_status & $\begin{array}{l}\text { : status perkawinan } \\
\text { responden }\end{array}$ \\
\hline ender & : jenis kelamin responden \\
\hline health_status & : status kesehatan responden \\
\hline$a_{i}$ & $\begin{array}{l}\text { : efek tetap di tingkat rumah } \\
\text { tangga }\end{array}$ \\
\hline & : error term \\
\hline
\end{tabular}

dimana:

$$
\begin{aligned}
& \text { fam_sat : komponen kepuasan } \\
& \text { keluarga kesejahteraan } \\
& \text { subjektif } \\
& \text { fut_pers : komponen persepsi masa } \\
& \text { depan kesejahteraan } \\
& \text { subjektif } \\
& \text { child :komponen kesejahteraan } \\
& \text { anak-anak dari } \\
& \text { kesejahteraan subjektif }
\end{aligned}
$$

\section{HASIL DAN PEMBAHASAN}

Menggunakan OLS robust standard error dan regresi efek tetap, penelitian ini membahas dampak tiga faktor penentu kesejahteraan subjektif, yaitu kepuasan keluarga, persepsi masa depan, dan kesejahteraan anak-anak. Dalam Lampiran 1, regresi OLS menunjukkan bahwa semua komponen kesejahteraan subjektif secara umum memiliki faktor penentu yang signifikan, meskipun kepuasan keluarga lebih sedikit memiliki faktor penentu yang signifikan dibandingkan persepsi masa depan dan kesejahteraan anak-anak. Sebagai perbandingan, regresi efek tetap menunjukkan lebih sedikit variabel signifikan ketika mengukur hasil kesejahteraan subjektif. OLS dan hasil regresi efek tetap secara lengkap ditunjukkan pada lampiran 1 terlampir.

Hasil estimasi OLS pada Lampiran 1 menunjukkan bahwa dampak UCT yang diterima oleh rumah tangga adalah negatif pada semua komponen kesejahteraan subjektif dan signifikan secara statistik pada satu persen. Ini bertentangan dengan asumsi umum bahwa bantuan tunai akan meningkatkan kesejahteraan subjektif. Kita juga dapat melihat pada Kolom 1, 3 dan 5 bahwa program UCT telah mengurangi skor kesejahteraan subjektif penerima program untuk kepuasan keluarga, persepsi masa depan, dan kesejahteraan anak-anak masing-masing dengan -31,5, -24,9, dan $-19,3$ poin persentase dibandingkan dengan rumah tangga non-penerima. Akan tetapi, hasil ini masih terindikasi bias oleh variabel yang dihilangkan karena dimasukkannya invarian waktu yang tidak diamati (invariant unobserved) dalam pendekatan OLS.

Di sisi lain, estimasi efek tetap (fixed effect) menunjukkan terdapat dampak UCT yang tidak signifikan atau tidak berdampak pada persepsi penerima manfaat di masa depan dan kesejahteraan anak-anak. Tetapi terdapat dampak positif sebesar 0,062 dan secara statistik signifikan pada sepuluh persen untuk kepuasan keluarga. Ini berarti bahwa rata-rata peningkatan satu persen dalam bantuan tunai langsung yang diterima meningkatkan skor kepuasan keluarga sebesar 6,2 poin persentase untuk penerima dibandingkan 
dengan bukan penerima. Selain itu, Berdasarkan hasil regresi efek tetap per indikator kesejahteraan subjektif dalam Lampiran 1 juga menunjukkan dampak positif UCT sebesar 0,0208 pada kehidupan keluarga, sebesar 0,0165 pada konsumsi makanan, dan sebesar 0,0097 pada tingkat kebahagiaan dengan signifikan secara statistik pada 5 persen, 10 persen dan 5 persen.

Oleh karena itu, bantuan langsung tunai masih bermanfaat bagi orang miskin selama guncangan ekonomi sementara, tetapi tidak mempengaruhi persepsi masa depan ataupun terhadap persepsi kesejahteraan anak-anak. Hasil efek tetap menunjukkan signifikansi berbeda dengan regresi OLS karena efek tetap juga digunakan untuk mengontrol perbedaan yang diamati dalam variabel tetap sepanjang waktu dan dapat merubah variabel regresi. Ini menunjukkan bahwa kesejahteraan subjektif lebih dipengaruhi oleh faktor-faktor yang tidak diamati (unobserved heterogeneity).

Hasil di atas juga menunjukkan bahwa peningkatan pendapatan yang dihasilkan oleh program UCT tidak memiliki banyak dampak pada kesejahteraan subjektif. Rojas (2008) menemukan hasil yang sama bahwa peningkatan pendapatan untuk orang miskin tidak secara otomatis meningkatkan kesejahteraan subjektif. Hal ini bertentangan dengan beberapa penulis yang menemukan bahwa peningkatan pendapatan yang disebabkan oleh program bantuan tunai memiliki efek positif pada aspek kesejahteraan subjektif seperti kepuasan hidup, kebahagiaan, dan persepsi masa depan. Peningkatan pendapatan dapat juga menyebabkan sedikit atau tidak ada peningkatan kesejahteraan, karena faktor-faktor non-ekonomi lain yang terlibat dalam kompleksitas domain kesejahteraan manusia. Terdapat hierarki kebutuhan dalam literatur tentang kebutuhan dasar sehingga orang yang tidak mampu memenuhi kebutuhan dasarnya akan mengalami tingkat kesejahteraan subjektif yang rendah. Untuk mencapai tingkat kesejahteraan subjektif yang tinggi, diperlukan batas pendapatan minimum untuk meningkatkan tingkat kebutuhan hidup orang miskin (Rojas, 2008).

Dalam konteks Indonesia, Rosfadhila, dkk. (2011) mengevaluasi implementasi program BLT dan menemukan beberapa permasalahan. Pertama, penerima BLT menyatakan bahwa bantuan tunai telah membantu meringankan beban ekonomi rumah tangga. Tetapi uang sebesar IDR 100.000 (sekitar USD 10) yang diterima dalam sebulan tidak cukup untuk memenuhi semua kebutuhan karena kenaikan harga. Kedua, program-program penyaluran dana menciptakan peluang untuk korupsi, seperti pemotongan yang dibuat secara kolusi antara pemimpin masyarakat dan rumah tangga sasaran. Pemotongan dana juga dimaksudkan untuk menghindari kecemburuan dan konflik di masyarakat, dan membantu membiayai berbagai kegiatan masyarakat. Penelitian oleh Listyaningsih, U \& Kiswanto, E (2009) juga menemukan kesalahan alokasi dana BLT. Dalam pelaksanaannya yang pertama di tahun 2005, rumah tangga yang tidak memenuhi kriteria secara keliru dimasukkan sebagai penerima, meskipun daftar penerima manfaat telah diperbaiki pada tahun 2008. Permasalahan tersebut di atas dapat juga berkontribusi pada kecilnya dampak BLT pada kesejahteraan subjektif.

Berdasarkan Lampiran 1 juga terlihat bahwa faktor penentu (variabel independen) selain bantuan tunai memiliki korelasi dan tanda yang sesuai dengan harapan. Selain itu, lebih dari setengah faktor penentu tersebut signifikan secara statistik. Ini konsisten dengan temuan Dolan, dkk. (2008), Kilburn, dkk. (2016), dan Rojas (2008) bahwa kesejahteraan subjektif dipengaruhi oleh faktor pribadi dan sosial (non-ekonomi) seperti status kesehatan, status perkawinan, jenis kelamin, pendidikan, dan ukuran rumah tangga.

Kepemilikan rumah umumnya menunjukkan korelasi positif dengan semua komponen kesejahteraan subjektif. Menggunakan OLS, kepemilikan rumah terlihat memiliki korelasi yang signifikan pada satu persen dengan semua variabel dependen kesejahteraan subjektif. Sementara itu, regresi efek tetap menunjukkan bahwa variabel kepemilikan rumah memiliki pengaruh yang signifikan secara statistik, positif terhadap kepuasan keluarga dan kesejahteraan anak-anak sebesar lima persen dan satu persen, tetapi tidak ada dampak signifikan pada persepsi masa depan. Dengan OLS, status rumah milik sendiri terlihat dapat meningkatkan skor kepuasan keluarga sebesar 23 poin persentase, skor persepsi masa depan sebesar tujuh poin persentase, dan skor kesejahteraan anak-anak sebesar 23 poin persentase lebih dari yang lain. Sementara itu, dengan efek tetap menunjukkan bahwa status rumah milik sendiri meningkatkan skor kepuasan keluarga sebesar sepuluh poin persentase dan skor kesejahteraan anak-anak sebesar 21 poin persentase lebih dari status kepemilikan rumah lain. Singkatnya, rumah tangga yang memiliki rumah sendiri terlihat menikmati kesejahteraan subjektif lebih tinggi dibandingkan dengan rumah tangga yang tidak memiliki rumah.

Faktor pendidikan berkorelasi positif dan signifikan dengan kepuasan keluarga, persepsi masa depan, dan kesejahteraan anak-anak karena hasil OLS menunjukkan bahwa responden dengan tingkat pendidikan lebih tinggi akan meningkatkan kesejahteraan subjektif. Jamal, H. (2018) menemukan hasil yang sama dimana tingkat pendidikan yang dicapai berkorelasi positif dan 
signifikan dengan kesejahteraan subjektif. Tetapi regresi efek tetap menunjukkan bahwa korelasi signifikan hanya ditemukan antara pendidikan tinggi dan kepuasan keluarga (pada lima persen), dan antara pendidikan sekolah dasar dan persepsi masa depan (pada sepuluh persen). Sementara itu, tidak ada dampak signifikan yang ditemukan bagi kesejahteraan anak-anak.

Lampiran 1 juga menunjukkan hasil regresi OLS yang sama dengan hasil regresi efek tetap untuk variabel ukuran rumah tangga (hhsize), yaitu, korelasi negatif yang signifikan terhadap persepsi masa depan dan kesejahteraan anak-anak, tetapi tidak signifikan dengan kepuasan keluarga. Baik menggunakan OLS atau efek tetap memperlihatkan hasil yaitu peningkatan satu anggota keluarga akan mengurangi skor persepsi masa depan sebesar dua poin persentase dan skor kesejahteraan anak-anak sebesar lima poin persentase. Temuan ini sesuai dengan Kilburn, dkk. (2016) yang menemukan korelasi negatif signifikan antara variabel komposisi rumah tangga dan kesejahteraan subjektif, menunjukkan bahwa semakin banyak anggota keluarga, semakin kecil kesejahteraan subjektif.

Secara keseluruhan, hasil OLS dan regresi efek tetap untuk usia dan usia kuadrat tidak menunjukkan dampak signifikan pada hasil kesejahteraan subjektif. Jika dilihat lebih dekat, regresi OLS menunjukkan bahwa variabel usia memiliki korelasi positif dengan signifikansi pada sepuluh persen pada persepsi masa depan dan korelasi negatif dengan signifikansi pada lima persen pada kesejahteraan anak-anak. Beberapa penelitian, seperti yang dilakukan oleh Jamal, $\mathrm{H}$. (2018), menyimpulkan bahwa kelompok usia yang lebih muda cenderung lebih bahagia daripada responden setengah baya, tetapi penelitian ini tidak menemukan bukti empiris untuk hubungan usia kuadrat.

Status perkawinan memberikan hasil regresi OLS positif dan signifikan pada satu persen untuk kepuasan keluarga dan kesejahteraan anak-anak tetapi tidak berdampak pada persepsi masa depan. Responden yang sudah menikah menikmati skor kepuasan keluarga sebesar 18 poin persentase dan skor kesejahteraan anak-anak 25 poin lebih tinggi dibandingkan responden yang belum menikah. Ini sesuai dengan Myers (2000) yang menyatakan bahwa orang yang menikah pada umumnya lebih bahagia daripada mereka yang belum menikah, apakah mereka berpisah, bercerai atau lajang. Sementara itu, regresi efek tetap menunjukkan bahwa variabel status pernikahan tidak mempengaruhi hasil kesejahteraan subjektif.

Hasil regresi OLS untuk gender menunjukkan bahwa variabel ini berkorelasi positif dan signifikan dengan semua output kesejahteraan subjektif masing-masing sebesar satu persen, sepuluh persen, dan lima persen untuk kepuasan keluarga, persepsi masa depan, dan kesejahteraan anak-anak. Kepala rumah tangga perempuan menunjukkan skor kepuasan keluarga sebesar 14 poin persentase, skor persepsi masa depan sebesar tujuh poin persentase, dan skor kesejahteraan anak-anak sebesar 12 poin persentase lebih tinggi daripada kepala rumah tangga laki-laki. Tetapi regresi efek tetap menunjukkan hasil tidak signifikan untuk semua komponen kesejahteraan subjektif. Dalam penelitian Dolan, dkk. (2008) menemukan hasil yang sama di mana perbedaan gender pada kepuasan hidup bervariasi dari satu negara ke negara, tetapi perbedaannya cenderung tidak signifikan di sebagian besar negara-negara Asia dan Barat.

Secara umum, satu-satunya determinan yang memiliki korelasi yang kuat, positif dan signifikan terhadap semua komponen kesejahteraan subjektif baik dianalisis dengan OLS maupun efek tetap adalah status kesehatan. Hal ini menunjukkan bahwa kondisi kesehatan seseorang sangat mempengaruhi kesejahteraan subjektifnya. Temuan ini sejalan dengan kesimpulan dari Dolan dkk. (2008) yang menyatakan bahwa studi secara konsisten menunjukkan hubungan kuat antara kesejahteraan subjektif (subjective wellbeing, SWB) dan kesehatan baik secara fisik dan maupun psikologis. Kesehatan psikologis lebih berkorelasi dengan kesejahteraan subjektif dibandingkan kesehatan fisik tetapi ini tidak mengejutkan mengingat adanya hubungan erat antara keduanya.

\section{KESIMPULAN DAN SARAN}

Bantuan Tunai Tanpa Syarat (Unconditional Cash Transfer/UCT) telah menjadi salah satu instrumen yang digunakan pemerintah untuk dapat membantu orang miskin memenuhi kebutuhan sehari-hari mereka. Dalam konteks Indonesia, studi evaluasi dampak telah dilakukan pada serangkaian program UCT menggunakan indikator ekonomi atau material. Tetapi saat ini kesepakatan luas tentang pentingnya konsepkonsep seperti kesejahteraan subjektif yang mengukur kualitas hidup sebagai pengalaman aktual melalui persepsi seseorang. Untuk membuat sketsa gambaran yang lebih lengkap dari masalah sosial saat ini, penelitian ini mencoba berkontribusi pada literatur tentang dampak aspek non-materi dari sudut pandang rumah tangga penerima.

Secara umum, program UCT di Indonesia berkorelasi negatif atau tidak berdampak pada peningkatan kesejahteraan subjektif rumah tangga penerima dibandingkan dengan non-penerima manfaat. Di antara tiga komponen kesejahteraan subjektif - kepuasan keluarga, persepsi masa 
depan, dan kesejahteraan anak-anak-program UCT memiliki dampak paling signifikan dan positif pada komponen kepuasan keluarga. Dari perspektif penerima, UCT dapat membantu penerima manfaat mempertahankan tingkat konsumsi yang stabil selama guncangan ekonomi jangka pendek dan tidak mempengaruhi persepsi mereka tentang masa depan dan persepsi kesejahteraan anak.

Hasil ini tidak sejalan dengan beberapa teori yang mengasumsikan bahwa bantuan tunai akan meningkatkan kesejahteraan subjektif. Beberapa faktor yang dapat menjelaskan hal ini, seperti jumlah uang tunai yang diberikan akan menentukan peningkatan konsumsi dan kesejahteraan psikologis (Haushofer, J. \& Shapiro, J., 2016). Selain itu, persepsi responden dapat dipengaruhi oleh lamanya waktu antara survei dan implementasi program (Natali dkk., 2018).

Lebih jauh lagi, program UCT Indonesia telah memiliki beberapa masalah dalam implementasinya yang mempengaruhi indikator kesejahteraan subjektif. Oleh karena itu pemerintah harus terus meningkatkan efektivitas pelaksanaan program, terutama terkait jumlah atau besaran bantuan tunai yang dirasa belum mencukupi kebutuhan penerima manfaat, penargetan rumah tangga untuk mencegah kesalahan alokasi, dan koordinasi semua lembaga terkait untuk menghilangkan peluang korupsi dan konflik sosial.

Pengukuran secara subjektif seperti kepuasan hidup merupakan dimensi penting kesejahteraan seseorang yang tidak dapat ditangkap oleh pengukuran objektif. Pembuat kebijakan harus mempertimbangkan aspek penilaian secara objektif dan subjektif secara bersamaan dalam rangka meningkatkan kualitas hidup masyarakat karena keduanya dapat mencerminkan kesejahteraan yang lebih akurat. Selain itu, kesejahteraan subjektif yang rendah tidak hanya disebabkan oleh rendahnya pendapatan orang miskin, tetapi juga faktor-faktor lain yang relevan terkait dengan kepuasan dalam berbagai bidang kehidupan. Studi ini dapat menginspirasi kebijakan publik untuk tidak hanya fokus pada peningkatan pendapatan masyarakat miskin tetapi juga menempatkan mereka dalam situasi yang memuaskan kehidupan (Rojas, 2008).

\section{IMPLIKASI DAN KETERBATASAN}

Literatur menunjukkan bahwa kesejahteraan subjektif adalah konsep yang sangat luas. Tentu saja, penelitian ini belum membahas semua unsur kesejahteraan subjektif dari bantuan tunai di Indonesia karena terbatasnya data, teknik penelitian, dan serta waktu yang tersedia. Survei di 13 provinsi di Indonesia menggunakan jumlah data yang terbatas sehingga diperlukan penelitian di masa depan yang dapat memperbaiki hal ini dengan menggunakan data yang memberikan representasi lebih baik dari masyarakat Indonesia. Studi yang sama juga akan mendapat akurasi hasil yang lebih baik jika mempertimbangkan jarak waktu antara survei dan pelaksanaan bantuan tunai, di mana periode waktu yang lebih pendek akan menghasilkan dampak yang lebih nyata (real time). Terlepas dari itu, temuan yang disajikan dalam penelitian ini dapat berkontribusi dan menjadi pertimbangan bagi studi selanjutnya di dalam topik ini.

\section{REFERENSI}

Attah, R., Barca, V., Kardan, A., and MacAuslan, I. (2016).Can social protection affect psychosocial wellbeing and why does this matter? lessons from cash transfers in Sub-Saharan Africa. Journal of development studies, 52(8), 11151131.

Bastagli, et al. (2016).Cash Transfers: What Does the Evidence Say? Overseas Development Institute Report.

Diener, E., Suh, E. M., Smith, H., \& Shao, L. (1995).National differences in reported subjective well-being: Why do they occur? Social Indicators Research, 34(1), 7-32.

Dolan, P., Peasgood, T., and White, M. (2008).Do we really know what makes us happy? a review of the economic literature on the factors associated with subjective well-being. Journal of economic psychology, 29(1), 94-122.

Eckersley, R. (2000).The mixed blessings of material progress: Diminishing returns in the pursuit of happiness. Journal of Happiness Studies, 1(3), 267-292.

Handa, S., Martorano, B., Halpern, C., Pettifor, A., \& Thirumurthy, H. (2014).Subjective Well-being, Risk Perceptions and Time Discounting: Evidence from a Large-Scale Cash Transfer Programme. UNICEF Office of Research-Innocenti.

Haushofer, J. \& Shapiro, J. (2016) .The short-term impact of unconditional cash transfers to the poor: experimental evidence from Kenya. The Quarterly Journal of Economics, 131(4), 19732042.

Helliwell, J. F. (2005).Well-being, social capital and public policy. What.s new? National Bureau of Economic Research, Working Paper 11807.

Honorati, M., Gentilini, U., \& R.G. Yemtsov. (2015). The State of Social Safety Nets 2015.Washington, DC: World Bank Group. 
Jamal, H. (2018).The Exploration of subjective wellbeing in the context of Pakistan. Munich Personal Repec Archive, 87950.

Junior, J.A., Katz, A.M., \& Ahn, R. (2016).The Perspectives of Young Women in Rural Western Kenya on Unconditional Cash Transfers. Poverty \& Public Policy, 8(1), 72-94.

Kahneman, D. \& A. Deaton. (2010).High income improves evaluation of life but not emotional well-being. Proceedings of the National Academy of Sciences of the United States of America, 107(38), 16489-16493.

Kilburn, K., Handa, S., Angeles, G., Mvula, P. \& Tsoka, M. (2016).Happiness and alleviation of income poverty: impacts of an unconditional cash transfer programme using a subjective well-being approach. UNICEF Office of Research.

Listyaningsih, U. \& E. Kiswanto. (2009).Bantuan langsung tunai mengatasi masalah dengan masalah. Populasi,20(1), 13-26.

Martínez, D.M. \& A.G. Maia, A.G. (2018).The impacts of cash transfers on subjective wellbeing and poverty: the case of Colombia. Journal of Family and Economic Issues, 39(4), 616-633.

Myers, D.G. (2000).The funds, friends, and faith of happy people. American psychologist, 55(1), 5667.

Natali, L., Handa, S., Peterman, A., Seidenfeld, D., Tembo, G., and Zambia Cash Transfer Evaluation Team. (2018). Does money buy happiness? evidence from an unconditional cash transfer in Zambia. SSM - population health, 4, 225-235.

Pega, F., Liu, S.Y., Walter, S., Pabayo, R., Saith, R. \& Lhachimi, S.K. (2017).Unconditional cash transfers for reducing poverty and vulnerabilities: effect on use of health services and health outcomes in low-and middle-income countries. Cochrane Database of Systematic Reviews (11).

Rawlings, L. B., \& Rubio, G. (2003). Evaluating the Impact of Conditional Cash Transfer Programs: Lessons from Latin America. Washington DC: The World Bank.

Rojas, M. (2008).Experienced Poverty and Income Poverty in Mexico: A Subjective Well-being Approach. World Development, 36(6), 10781093.

Rojas, M. (2009).Enhancing Poverty-Abatement Programs: A Subjective Well-being Contribution. Applied Research in Quality of Life, 4(2), 179-199.

Rosfadhila, M., Toyamah, N., Sulaksono, B., Devina, S., Sodo, R.J., and Syukri, M. (2011).Kajian cepat pelaksanaan program bantuan langsung tunai (BLT) 2008 dan evaluasi penerima program BLT 2005 di Indonesia. SMERU Research Institute, 1-107.

Saavedra, J.E. (2016).The effects of conditional cash transfer programs on poverty reduction, human capital accumulation and wellbeing. United Nations Expert Group Meeting on "Strategies for eradicating poverty to achieve sustainable development for all" convened in New York on June, pp1-3.

Samuel, F. \& Stavropoulou, M. (2016).Being able to breathe again: the effects of cash transfer programmes on psychosocial wellbeing. The Journal of Development Studies, 52(8), 10991114.

Wills, E. (2009).Spirituality and subjective wellbeing: evidences for a new domain in the personal well-being index. Journal of Happiness Studies, 10(1), 49-69.

Wooldridge, J. M. (2006). Introductory econometrics: A modern approach. Mason, $\mathrm{OH}$ : Thomson/South-Western. 


\section{LAMPIRAN \\ ILUSTRASI TABEL}

Lampiran 1. OLS and Fixed Effect Regression Result

\begin{tabular}{|c|c|c|c|c|c|c|}
\hline \multirow{3}{*}{ Variables } & \multicolumn{2}{|c|}{ Family Satisfaction } & \multicolumn{2}{|c|}{ Future Perception } & \multicolumn{2}{|c|}{ Children } \\
\hline & OLS & Fixed Effect & OLS & Fixed Effect & OLS & Fixed Effect \\
\hline & $(1)$ & (2) & (3) & (4) & (5) & (6) \\
\hline \multirow[t]{2}{*}{ UCT } & $-0.3149^{* * *}$ & $0.0627^{*}$ & $-0.2488^{* * *}$ & -0.0601 & $-0.1930^{* * *}$ & 0.0339 \\
\hline & $(0.0223)$ & $(0.0361)$ & $(0.0232)$ & $(0.0408)$ & $(0.0276)$ & $(0.0529)$ \\
\hline \multirow[t]{2}{*}{ Urban } & $0.1107^{* * *}$ & -0.0183 & $0.0371 *$ & -0.0110 & $0.1151^{* * *}$ & -0.0848 \\
\hline & $(0.0204)$ & $(0.0509)$ & $(0.0214)$ & $(0.0576)$ & $(0.0256)$ & $(0.0752)$ \\
\hline \multirow[t]{2}{*}{ home_ownership } & $0.2280^{* * *}$ & $0.1006^{* *}$ & $0.0717^{* * *}$ & -0.0128 & $0.2267^{* * *}$ & $0.2089^{* * *}$ \\
\hline & $(0.0257)$ & $(0.0407)$ & $(0.0264)$ & $(0.0460)$ & $(0.0297)$ & $(0.0533)$ \\
\hline \multirow[t]{2}{*}{$\begin{array}{l}\text { 1. Elementary } \\
\text { school }\end{array}$} & $0.1455^{* * *}$ & 0.0818 & $0.1356^{* * *}$ & $0.1373^{*}$ & $0.1614^{* *}$ & 0.1910 \\
\hline & $(0.0416)$ & $(0.0702)$ & $(0.0489)$ & $(0.0795)$ & $(0.0672)$ & $(0.1592)$ \\
\hline \multirow[t]{2}{*}{$\begin{array}{l}\text { 2. Senior high } \\
\text { school }\end{array}$} & $0.3969 * * *$ & 0.0604 & $0.2526^{* * *}$ & 0.1138 & $0.3732^{* * *}$ & 0.0490 \\
\hline & $(0.0443)$ & $(0.0870)$ & $(0.0515)$ & $(0.0984)$ & $(0.0687)$ & $(0.1760)$ \\
\hline \multirow[t]{2}{*}{$\begin{array}{l}\text { 3. Higher } \\
\text { education }\end{array}$} & $0.7956^{* * *}$ & $0.2794^{* *}$ & $0.5136^{* * *}$ & 0.1546 & $0.6774^{* * *}$ & -0.0119 \\
\hline & $(0.0619)$ & $(0.1300)$ & $(0.0651)$ & $(0.1471)$ & $(0.0842)$ & $(0.2324)$ \\
\hline \multirow[t]{2}{*}{ Hhsize } & -0.0050 & -0.0047 & $-0.0214^{* * *}$ & $-0.0213^{*}$ & $-0.0503^{* * *}$ & $-0.0477^{* *}$ \\
\hline & $(0.0063)$ & $(0.0106)$ & $(0.0064)$ & $(0.0120)$ & $(0.0092)$ & $(0.0194)$ \\
\hline \multirow[t]{2}{*}{ Age } & -0.0058 & 0.0024 & $0.0094^{*}$ & -0.0129 & $-0.0218^{* *}$ & 0.0030 \\
\hline & $(0.0046)$ & $(0.0084)$ & $(0.0052)$ & $(0.0095)$ & $(0.0092)$ & $(0.0195)$ \\
\hline \multirow[t]{2}{*}{ age2 } & 0.0001 & -0.0001 & 0.0000 & 0.0001 & 0.0002 & -0.0003 \\
\hline & $(0.0000)$ & $(0.0001)$ & $(0.0001)$ & $(0.0001)$ & $(0.0001)$ & $(0.0002)$ \\
\hline \multirow[t]{2}{*}{ marital_status } & $0.1798^{* * *}$ & 0.0333 & 0.0099 & -0.0415 & $0.2521^{* * *}$ & 0.0055 \\
\hline & $(0.0397)$ & $(0.0585)$ & $(0.0422)$ & $(0.0662)$ & $(0.0753)$ & $(0.1288)$ \\
\hline \multirow[t]{2}{*}{ Gender } & $0.1404^{* * *}$ & 0.0911 & $0.0741^{*}$ & 0.0852 & $0.1194^{* *}$ & 0.0389 \\
\hline & $(0.0401)$ & $(0.0595)$ & $(0.0404)$ & $(0.0673)$ & $(0.0550)$ & $(0.0957)$ \\
\hline \multirow[t]{2}{*}{ health_status } & $0.3913^{* * *}$ & $0.2410^{* * *}$ & $0.1838^{* * *}$ & $0.0837^{* *}$ & $0.3874^{* * *}$ & $0.2618^{* * *}$ \\
\hline & $(0.0259)$ & $(0.0333)$ & $(0.0271)$ & $(0.0377)$ & $(0.0346)$ & $(0.0525)$ \\
\hline \multirow[t]{2}{*}{ year_base } & & $0.3824^{* * *}$ & & $0.1834^{* * *}$ & & $0.1340^{* * *}$ \\
\hline & & $(0.0208)$ & & $(0.0235)$ & & $(0.0461)$ \\
\hline \multirow[t]{2}{*}{ Constant } & $4.1533^{* * *}$ & $4.4301^{* * *}$ & $2.8572^{* * *}$ & $3.7411^{* * *}$ & $3.6946^{* * *}$ & $4.0174^{* * *}$ \\
\hline & $(0.1131)$ & $(0.2300)$ & $(0.1275)$ & $(0.2602)$ & $(0.2111)$ & $(0.4880)$ \\
\hline Observations & 11,340 & 11,340 & 11,340 & 11,340 & 6,909 & 6,909 \\
\hline R-squared & 0.0870 & 0.0850 & 0.0353 & 0.0181 & 0.0846 & 0.0294 \\
\hline Number of hhid & & 5,670 & & 5,670 & & 4,178 \\
\hline
\end{tabular}

Robust standard errors in parentheses ${ }^{* * *} \mathrm{p}<0.01,{ }^{* *} \mathrm{p}<0.05,{ }^{*} \mathrm{p}<0.1$

Source: STATA results and author's own calculation 
Lampiran 2. Hasil Regresi Efek Tetap (Fixed Effect) per Variabel Indikator Kesejahteraan Subjektif

\begin{tabular}{|c|c|c|c|c|c|c|}
\hline VARIABLES & $\begin{array}{c}\text { (1) } \\
\text { lvl_pov }\end{array}$ & $\begin{array}{c}\text { (2) } \\
\text { fam_life }\end{array}$ & $\begin{array}{c}\text { (3) } \\
\text { std_liv }\end{array}$ & $\begin{array}{c}\text { (4) } \\
\text { food_cons }\end{array}$ & $\begin{array}{c}\text { (5) } \\
\text { healthcar } \\
\mathrm{e}\end{array}$ & $\begin{array}{c}\text { (6) } \\
\text { lvl_happy }\end{array}$ \\
\hline UCT & $\begin{array}{l}-0.0025 \\
(0.0095)\end{array}$ & $\begin{array}{l}0.0208^{* *} \\
(0.0100)\end{array}$ & $\begin{array}{c}0.0064 \\
(0.0108)\end{array}$ & $\begin{array}{l}0.0165^{*} \\
(0.0095)\end{array}$ & $\begin{array}{c}0.0119 \\
(0.0100)\end{array}$ & $\begin{array}{l}0.0097 * * \\
(0.0049)\end{array}$ \\
\hline urban & $\begin{array}{c}0.0135 \\
(0.0133)\end{array}$ & $\begin{array}{c}0.0025 \\
(0.0141)\end{array}$ & $\begin{array}{l}-0.0119 \\
(0.0153)\end{array}$ & $\begin{array}{c}-0.0203 \\
(0.0134)\end{array}$ & $\begin{array}{c}-0.0058 \\
(0.0141)\end{array}$ & $\begin{array}{c}0.0038 \\
(0.0068)\end{array}$ \\
\hline home_ownership & $\begin{array}{c}0.0369^{* * *} \\
(0.0107)\end{array}$ & $\begin{array}{c}0.0141 \\
(0.0113)\end{array}$ & $\begin{array}{c}0.0172 \\
(0.0122)\end{array}$ & $\begin{array}{c}0.0154 \\
(0.0107)\end{array}$ & $\begin{array}{c}0.0180 \\
(0.0112)\end{array}$ & $\begin{array}{c}-0.0010 \\
(0.0055)\end{array}$ \\
\hline 1.educational_level & $\begin{array}{c}0.0066 \\
(0.0184)\end{array}$ & $\begin{array}{c}0.0223 \\
(0.0195)\end{array}$ & $\begin{array}{c}0.0145 \\
(0.0211)\end{array}$ & $\begin{array}{c}0.0171 \\
(0.0185)\end{array}$ & $\begin{array}{c}0.0159 \\
(0.0194)\end{array}$ & $\begin{array}{c}0.0055 \\
(0.0094)\end{array}$ \\
\hline 2.educational_level & $\begin{array}{l}-0.0028 \\
(0.0228)\end{array}$ & $\begin{array}{c}0.0094 \\
(0.0242)\end{array}$ & $\begin{array}{c}-0.0026 \\
(0.0261)\end{array}$ & $\begin{array}{c}0.0234 \\
(0.0229)\end{array}$ & $\begin{array}{c}0.0299 \\
(0.0241)\end{array}$ & $\begin{array}{c}0.0031 \\
(0.0117)\end{array}$ \\
\hline 3.educational_level & $\begin{array}{c}0.0295 \\
(0.0341)\end{array}$ & $\begin{array}{c}0.0482 \\
(0.0361)\end{array}$ & $\begin{array}{c}0.0389 \\
(0.0390)\end{array}$ & $\begin{array}{l}0.0723^{* *} \\
(0.0342)\end{array}$ & $\begin{array}{l}0.0768^{* *} \\
(0.0359)\end{array}$ & $\begin{array}{c}0.0138 \\
(0.0175)\end{array}$ \\
\hline hhsize & $\begin{array}{c}0.0038 \\
(0.0028)\end{array}$ & $\begin{array}{c}0.0003 \\
(0.0030)\end{array}$ & $\begin{array}{l}-0.0010 \\
(0.0032)\end{array}$ & $\begin{array}{c}-0.0038 \\
(0.0028)\end{array}$ & $\begin{array}{c}-0.0062^{* *} \\
(0.0029)\end{array}$ & $\begin{array}{c}0.0023 \\
(0.0014)\end{array}$ \\
\hline age & $\begin{array}{c}0.0003 \\
(0.0022)\end{array}$ & $\begin{array}{c}0.0008 \\
(0.0023)\end{array}$ & $\begin{array}{l}-0.0010 \\
(0.0025)\end{array}$ & $\begin{array}{c}0.0000 \\
(0.0022)\end{array}$ & $\begin{array}{c}-0.0006 \\
(0.0023)\end{array}$ & $\begin{array}{l}0.0028^{* *} \\
(0.0011)\end{array}$ \\
\hline age2 & $\begin{array}{l}-0.0000 \\
(0.0000)\end{array}$ & $\begin{array}{l}-0.0000 \\
(0.0000)\end{array}$ & $\begin{array}{l}-0.0000 \\
(0.0000)\end{array}$ & $\begin{array}{c}-0.0000 \\
(0.0000)\end{array}$ & $\begin{array}{c}-0.0000 \\
(0.0000)\end{array}$ & $\begin{array}{c}-0.0000^{* * *} \\
(0.0000)\end{array}$ \\
\hline marital_status & $\begin{array}{c}-0.0084 \\
(0.0153)\end{array}$ & $\begin{array}{c}0.0028 \\
(0.0162)\end{array}$ & $\begin{array}{c}-0.0020 \\
(0.0175)\end{array}$ & $\begin{array}{c}-0.0045 \\
(0.0154)\end{array}$ & $\begin{array}{c}-0.0003 \\
(0.0162)\end{array}$ & $\begin{array}{c}0.0456^{* * *} \\
(0.0079)\end{array}$ \\
\hline gender & $\begin{array}{l}0.0329^{* *} \\
(0.0156)\end{array}$ & $\begin{array}{c}0.0264 \\
(0.0165)\end{array}$ & $\begin{array}{c}0.0157 \\
(0.0178)\end{array}$ & $\begin{array}{c}-0.0030 \\
(0.0157)\end{array}$ & $\begin{array}{c}0.0144 \\
(0.0164)\end{array}$ & $\begin{array}{c}0.0047 \\
(0.0080)\end{array}$ \\
\hline health_status & $\begin{array}{c}0.0129 \\
(0.0087)\end{array}$ & $\begin{array}{c}0.0484^{* * *} \\
(0.0092)\end{array}$ & $\begin{array}{c}0.0377^{* * *} \\
(0.0100)\end{array}$ & $\begin{array}{c}0.0330^{* * *} \\
(0.0088)\end{array}$ & $\begin{array}{c}0.0843^{* * *} \\
(0.0092)\end{array}$ & $\begin{array}{c}0.0247^{* * *} \\
(0.0045)\end{array}$ \\
\hline year_base & $\begin{array}{c}0.1811^{* * *} \\
(0.0055)\end{array}$ & $\begin{array}{c}-0.0330^{* * *} \\
(0.0058)\end{array}$ & $\begin{array}{l}-0.0050 \\
(0.0062)\end{array}$ & $\begin{array}{c}-0.0213^{* * *} \\
(0.0055)\end{array}$ & $\begin{array}{c}-0.1321^{* * *} \\
(0.0058)\end{array}$ & $\begin{array}{c}0.3927^{* * *} \\
(0.0028)\end{array}$ \\
\hline Constant & $\begin{array}{c}0.5898^{* * *} \\
(0.0603)\end{array}$ & $\begin{array}{c}0.8143^{* * *} \\
(0.0639)\end{array}$ & $\begin{array}{c}0.9204^{* * *} \\
(0.0689)\end{array}$ & $\begin{array}{l}0.8940^{* * *} \\
(0.0605)\end{array}$ & $\begin{array}{c}0.8121^{* * *} \\
(0.0636)\end{array}$ & $\begin{array}{c}0.3996^{* * *} \\
(0.0309)\end{array}$ \\
\hline Observations & 11,340 & 11,340 & 11,340 & 11,340 & 11,340 & 11,340 \\
\hline R-squared & 0.2366 & 0.0223 & 0.0065 & 0.0134 & 0.1664 & 0.8466 \\
\hline Number of hhid & 5,670 & 5,670 & 5,670 & 5,670 & 5,670 & 5,670 \\
\hline
\end{tabular}

Standard errors in parentheses

${ }^{* * *} \mathrm{p}<0.01,{ }^{* *} \mathrm{p}<0.05,{ }^{*} \mathrm{p}<0.1$ 


\begin{tabular}{|c|c|c|c|c|c|c|}
\hline VARIABLES & $\begin{array}{c}\text { (7) } \\
\text { ftr_pov }\end{array}$ & $\begin{array}{c}\text { (8) } \\
\text { ftr_stnd }\end{array}$ & $\begin{array}{c}\text { (9) } \\
\text { child_std } \\
\end{array}$ & $\begin{array}{c}(10) \\
\text { child_foo } \\
\text { d }\end{array}$ & $\begin{array}{c}\text { (11) } \\
\text { child_health } \\
\end{array}$ & $\begin{array}{c}\text { (12) } \\
\text { child_edu }\end{array}$ \\
\hline UCT & $\begin{array}{c}-0.0110 \\
(0.0290)\end{array}$ & $\begin{array}{l}-0.0491^{*} \\
(0.0273)\end{array}$ & $\begin{array}{c}0.0073 \\
(0.0165)\end{array}$ & $\begin{array}{c}0.0130 \\
(0.0159)\end{array}$ & $\begin{array}{c}0.0113 \\
(0.0167)\end{array}$ & $\begin{array}{c}0.0023 \\
(0.0193)\end{array}$ \\
\hline urban & $\begin{array}{c}-0.0105 \\
(0.0409)\end{array}$ & $\begin{array}{c}-0.0005 \\
(0.0385)\end{array}$ & $\begin{array}{c}-0.0342 \\
(0.0234)\end{array}$ & $\begin{array}{c}0.0049 \\
(0.0226)\end{array}$ & $\begin{array}{l}-0.0064 \\
(0.0237)\end{array}$ & $\begin{array}{l}-0.0491^{*} \\
(0.0274)\end{array}$ \\
\hline home_ownership & $\begin{array}{c}-0.0174 \\
(0.0327)\end{array}$ & $\begin{array}{c}0.0046 \\
(0.0308)\end{array}$ & $\begin{array}{c}0.0516^{* * *} \\
(0.0166)\end{array}$ & $\begin{array}{c}0.0605^{* * *} \\
(0.0160)\end{array}$ & $\begin{array}{c}0.0549 * * * \\
(0.0168)\end{array}$ & $\begin{array}{l}0.0419 * * \\
(0.0194)\end{array}$ \\
\hline 1.educational_level & $\begin{array}{c}0.0756 \\
(0.0564)\end{array}$ & $\begin{array}{c}0.0618 \\
(0.0532)\end{array}$ & $\begin{array}{c}0.0305 \\
(0.0496)\end{array}$ & $\begin{array}{c}0.0758 \\
(0.0478)\end{array}$ & $\begin{array}{c}0.0604 \\
(0.0501)\end{array}$ & $\begin{array}{c}0.0243 \\
(0.0579)\end{array}$ \\
\hline 2.educational_level & $\begin{array}{c}0.0426 \\
(0.0699)\end{array}$ & $\begin{array}{c}0.0711 \\
(0.0658)\end{array}$ & $\begin{array}{c}-0.0088 \\
(0.0548)\end{array}$ & $\begin{array}{c}0.0512 \\
(0.0528)\end{array}$ & $\begin{array}{c}0.0227 \\
(0.0554)\end{array}$ & $\begin{array}{l}-0.0162 \\
(0.0641)\end{array}$ \\
\hline 3.educational_level & $\begin{array}{c}0.0964 \\
(0.1044)\end{array}$ & $\begin{array}{c}0.0582 \\
(0.0983)\end{array}$ & $\begin{array}{c}-0.0447 \\
(0.0724)\end{array}$ & $\begin{array}{c}0.0569 \\
(0.0698)\end{array}$ & $\begin{array}{c}0.0301 \\
(0.0732)\end{array}$ & $\begin{array}{c}-0.0542 \\
(0.0846)\end{array}$ \\
\hline hhsize & $\begin{array}{c}-0.0047 \\
(0.0086)\end{array}$ & $\begin{array}{c}-0.0166^{* *} \\
(0.0081)\end{array}$ & $\begin{array}{c}-0.0056 \\
(0.0061)\end{array}$ & $\begin{array}{c}-0.0161^{* * *} \\
(0.0058)\end{array}$ & $\begin{array}{c}-0.0074 \\
(0.0061)\end{array}$ & $\begin{array}{c}-0.0186^{* * *} \\
(0.0071)\end{array}$ \\
\hline age & $\begin{array}{c}-0.0080 \\
(0.0068)\end{array}$ & $\begin{array}{l}-0.0049 \\
(0.0064)\end{array}$ & $\begin{array}{c}0.0085 \\
(0.0061)\end{array}$ & $\begin{array}{c}0.0082 \\
(0.0058)\end{array}$ & $\begin{array}{c}0.0064 \\
(0.0061)\end{array}$ & $\begin{array}{c}-0.0201^{* * *} \\
(0.0071)\end{array}$ \\
\hline age2 & $\begin{array}{c}0.0001 \\
(0.0001)\end{array}$ & $\begin{array}{c}0.0000 \\
(0.0001)\end{array}$ & $\begin{array}{c}-0.0002^{* * *} \\
(0.0001)\end{array}$ & $\begin{array}{c}-0.0002^{* *} \\
(0.0001)\end{array}$ & $\begin{array}{c}-0.0001^{* *} \\
(0.0001)\end{array}$ & $\begin{array}{l}0.0002^{* *} \\
(0.0001)\end{array}$ \\
\hline marital_status & $\begin{array}{c}-0.1004^{* *} \\
(0.0470)\end{array}$ & $\begin{array}{c}0.0589 \\
(0.0443)\end{array}$ & $\begin{array}{c}-0.0028 \\
(0.0401)\end{array}$ & $\begin{array}{c}0.0433 \\
(0.0387)\end{array}$ & $\begin{array}{c}-0.0293 \\
(0.0406)\end{array}$ & $\begin{array}{l}-0.0057 \\
(0.0469)\end{array}$ \\
\hline gender & $\begin{array}{c}0.0275 \\
(0.0478)\end{array}$ & $\begin{array}{c}0.0577 \\
(0.0450)\end{array}$ & $\begin{array}{c}0.0123 \\
(0.0298)\end{array}$ & $\begin{array}{c}0.0219 \\
(0.0287)\end{array}$ & $\begin{array}{c}0.0245 \\
(0.0302)\end{array}$ & $\begin{array}{c}-0.0198 \\
(0.0348)\end{array}$ \\
\hline health_status & $\begin{array}{c}0.0030 \\
(0.0268)\end{array}$ & $\begin{array}{c}0.0807^{* * *} \\
(0.0252)\end{array}$ & $\begin{array}{c}0.0674^{* * *} \\
(0.0164)\end{array}$ & $\begin{array}{c}0.0604^{* * *} \\
(0.0158)\end{array}$ & $\begin{array}{c}0.0672^{* * *} \\
(0.0165)\end{array}$ & $\begin{array}{c}0.0668^{* * *} \\
(0.0191)\end{array}$ \\
\hline year_base & $\begin{array}{c}-0.0158 \\
(0.0167)\end{array}$ & $\begin{array}{c}0.1991^{* * *} \\
(0.0157)\end{array}$ & $\begin{array}{c}-0.0060 \\
(0.0144)\end{array}$ & $\begin{array}{l}0.0308^{* *} \\
(0.0138)\end{array}$ & $\begin{array}{c}0.0225 \\
(0.0145)\end{array}$ & $\begin{array}{c}0.0867^{* * *} \\
(0.0168)\end{array}$ \\
\hline Constant & $\begin{array}{c}2.0247^{* * *} \\
(0.1848)\end{array}$ & $\begin{array}{c}1.7163^{* * *} \\
(0.1740)\end{array}$ & $\begin{array}{c}0.9163^{* * *} \\
(0.1519)\end{array}$ & $\begin{array}{c}0.8663^{* * *} \\
(0.1465)\end{array}$ & $\begin{array}{c}0.9292^{* * *} \\
(0.1537)\end{array}$ & $\begin{array}{c}1.3056^{* * *} \\
(0.1776)\end{array}$ \\
\hline Observations & 11,340 & 11,340 & 6,909 & 6,909 & 6,909 & 6,909 \\
\hline $\begin{array}{l}\text { R-squared } \\
\text { Number of hhid }\end{array}$ & $\begin{array}{c}0.0037 \\
5,670\end{array}$ & $\begin{array}{c}0.0419 \\
5,670\end{array}$ & $\begin{array}{c}0.0393 \\
4,178\end{array}$ & $\begin{array}{c}0.0226 \\
4,178\end{array}$ & $\begin{array}{c}0.0214 \\
4,178 \\
\end{array}$ & $\begin{array}{c}0.0191 \\
4,178 \\
\end{array}$ \\
\hline
\end{tabular}

Standard errors in parentheses

*** $\mathrm{p}<0.01,{ }^{* *} \mathrm{p}<0.05,{ }^{*} \mathrm{p}<0.1$ 